\title{
In vitro and in vivo antibacterial activities of cranberry press cake extracts alone or in combination with $\beta$-lactams against Staphylococcus aureus
}

Moussa S Diarra', Glenn Block', Heidi Rempel', B Dave Oomah², Judy Harrison², Jason McCallum³, Simon Boulanger ${ }^{4}$, Éric Brouillette ${ }^{4}$, Mariza Gattuso ${ }^{4}$ and François Malouin ${ }^{4 *}$

\begin{abstract}
Background: Cranberry fruits possess many biological activities partly due to their various phenolic compounds; however the underlying modes of action are poorly understood. We studied the effect of cranberry fruit extracts on the gene expression of Staphylococcus aureus to identify specific cellular processes involved in the antibacterial action.

Methods: Transcriptional profiles of four S. aureus strains grown in broth supplemented or not with $2 \mathrm{mg} / \mathrm{ml}$ of a commercial cranberry preparation (Nutricran ${ }^{\circledR} 90$ ) were compared using DNA arrays to reveal gene modulations serving as markers for biological activity. Ethanol extracted pressed cakes from fresh fruits also produced various fractions and their effects on marker genes were demonstrated by qPCR. Minimal inhibitory concentrations (MICs) of the most effective cranberry fraction (FC111) were determined against multiple $S$. aureus strains and drug interactions with $\beta$-lactam antibiotics were also evaluated. Incorporation assays with $\left.{ }^{3} \mathrm{H}\right]$-radiolabeled precursors were performed to evaluate the effect of FC111 on DNA, RNA, peptidoglycan (PG) and protein biosynthesis.

Results: Treatment of $S$. aureus with Nutricran ${ }^{\circledR} 90$ or $F C 111$ revealed a transcriptional signature typical of PG-acting antibiotics (up-regulation of genes vraR/S, murZ, lytM, pbp2, sgtB, fmt). The effect of FC111 on PG was confirmed by the marked inhibition of incorporation of D-[ $\left.{ }^{3} \mathrm{H}\right]$ alanine. The combination of $\beta$-lactams and FC111 in checkerboard assays revealed a synergistic activity against $S$. aureus including strain MRSA COL, which showed a 512-fold drop of amoxicillin MIC in the presence of FC111 at MIC/8. Finally, a therapeutic proof of concept was established in a mouse mastitis model of infection. S. aureus-infected mammary glands were treated with amoxicillin, FC111 or a combination of both; only the combination significantly reduced bacterial counts from infected glands $(P<0.05)$ compared to the untreated mice.

Conclusions: The cranberry fraction FC111 affects PG synthesis of S. aureus and acts in synergy with $\beta$-lactam antibiotics. Such a fraction easily obtained from poorly exploited press-cake residues, may find interesting applications in the agri-food sector and help reduce antibiotic usage in animal food production.
\end{abstract}

Keywords: Cranberry (Vaccinium macrocarpon Ait), Staphylococcus aureus, MRSA, Cell wall peptidoglycan, B-lactam, Synergy, Bovine mastitis

\footnotetext{
* Correspondence: Francois.Malouin@USherbrooke.ca

${ }^{4}$ Département de Biologie, Centre d'Étude et de Valorisation de la Diversité

Microbienne (CEVDM), Faculté des Sciences, Université de Sherbrooke,

Sherbrooke, QC J1K 2R1, Canada

Full list of author information is available at the end of the article
} 


\section{Background}

Staphylococcus aureus is an opportunistic pathogen responsible for many infectious diseases in humans and animals [1]. This bacterium is among the most prevalent causes of food poisoning gastroenteritis worldwide [2], as well as a leading cause of intramammary infections (gland inflammation, mastitis) in cows, milk quality and yield reduction, and major economic losses for the dairy industry [3]. In poultry, S. aureus induces infections having a major impact on the fertility and productivity of a breeder flock. Infections by $S$. aureus can occur in the joints or as a generalized infection (septicemia). Manifestations with more important economic consequences include synovitis with arthritis, osteomyelitis, and dermatitis [4]. Early efficient treatment of infection is paramount to avoid development of a chronic infection, acute infection resulting in irreversible tissue necrosis, or exacerbation leading to organ failure [5]. However, treating S. aureus infections becomes increasingly challenging due to its capacity to develop enhanced antibiotic resistance. Such resistance has developed due to the protective effects provided by biofilm production [6], chromosomal mutations, the acquisition or expression of various antibiotic resistance genes including those encoding low-affinity penicillin-binding proteins (PBPs) involved in cell wall peptidoglycan biosynthesis, and efflux pumps $[7,8]$.

The first report of a penicillin-resistant $S$. aureus occurred in the 1940s, followed by the emergence of methicillin-resistant S. aureus (MRSA) strains, which possess the low-affinity PBP2A encoded by the mecA gene. These now multi-resistant strains can induce various nosocomial and community-associated infections [9]. The emergence and widespread occurrence of hospital and community acquired MRSA as well as livestock-associated MRSA resulted from antibiotic selection pressure and horizontal and vertical gene transfers [10]. Concerning livestock, a high prevalence of MRSA was reported in pigs and pig farmers [11], and in Europe, MRSA strains found primarily in pigs are now a leading cause of communityassociated MRSA infections in humans [12]. Similarly, the recent emergence of bovine MRSA is also a concern since these strains are transmittable to humans [13,14]. The occurrence of MRSA among companion and food-producing animals and possible impact on human health has been reviewed by Petinaki and Spiliopoulou [15]. New research approaches, novel sources of antibiotic compounds and discovery of original microbial cell targets need to be developed in order to overcome multi-resistant bacteria such as MRSA.

The urge to bring forth novel antibiotic molecules hastened the investigation of the perspectives offered by plants. As such, many studies on berry fruits have shown the presence of large scale bioactive compounds such as cancer cell growth inhibitors, antimicrobial molecules, and antioxidants [16-18]. Cranberry (Vaccinium macrocarpon Ait) is one of the berries having the most potent antimicrobial effects against several human pathogens. We showed a lower mortality rate in chickens fed a commercial cranberry fruit extract $\left(\right.$ Nutricran $\left.{ }^{\circledR} 90\right)$ in feed compared to a non-supplemented control diet and that feeding birds diets containing cranberry fruit extract was effective in influencing the populations of bacteria such as Enterococcus [19]. The mechanism underlining this observation is unknown, however our study suggests that cranberry extract causes a shift in the bacterial population in the intestinal tract. Water-soluble phenolic compounds of cranberry juice, such as flavonoids (ex: anthocyanins and flavonols), have higher antimicrobial activities against foodborne pathogens than apolar phenolic compounds like polymeric tannins [16]. The bacterial cell wall and cellular membranes have been identified as targets of cranberry extracts on Gram-negative and Gram-positive foodborne pathogens like Escherichia coli O157:H7 and S. aureus [20], however, information is limited regarding the mechanism of action of cranberry on bacteria.

In this work, we have investigated the effect of Nutricran ${ }^{\circledR} 90$, and three extracts obtained from fresh cranberry fruits, on the transcriptional profiles of $S$. aureus, to provide insights on the antibacterial modes of action of such preparations. We identified a transcriptional signature that reveals inhibition of bacterial peptidoglycan biosynthesis. We also demonstrated the bactericidal effect of a combination of a cranberry extract and $\beta$-lactams in vitro, and the therapeutic usefulness of such a synergistic combination of agents in a mouse mastitis model of infection.

\section{Methods}

\section{Bacterial strains and growth conditions}

The antibiotic susceptibility testing reference strain Staphylococcus aureus ATCC 29213, the sequenced MRSA strains COL and N315, as well as the bovine mastitis isolates: Newbould (ATCC 29740), SHY97-4320 and SHY97-3906, were used in this study. Strains SHY974320 and SHY97-3906 were isolated from clinical mastitis and were previously described [21]. Bacteria stocks were kept frozen at $-80^{\circ} \mathrm{C}$ and grown on Mueller Hinton agar or Cation adjusted Muller Hinton broth (CAMHB, Becton Dickinson, Mississauga, ON, Canada). Viable bacterial counts (CFU) were determined on Tryptic Soy agar (TSA, Becton Dickinson).

\section{Cranberry products, antibiotics and chemical reagents}

A commercial cranberry product, Nutricran ${ }^{\circledR} 90$ (NC90), was obtained from Decas Botanical Synergies (Wareham, MA, USA). The NC90 contained at least $88 \%$ carbohydrates, $30 \%$ organic acids, 2 to $3.8 \%$ total phenolic compounds, 0.3 to $1 \%$ anthocyanins, 0.8 to $1.5 \%$ 
proanthocyanidins, 300 to $435 \mu \mathrm{g} / \mathrm{g}$ of quercetin, and was $100 \%$ soluble in water as described by the manufacturer. Laboratory and pilot-scale preparations of extracts were performed with fresh Ben Lear cranberries obtained from a local farm (Agassiz, British Columbia, Canada) or from Ocean Spray (Langley, BC, Canada) as described previously [17]. Chloramphenicol, oxacillin, amoxicillin, norfloxacin, rifampicin and vancomycin were purchased from Sigma Aldrich (Oakville, Ontario, Canada).

\section{Preparation of cranberry press cake extracts}

Laboratory-scale fraction were obtained from $2 \mathrm{Kg}$ of fresh fruits which were hammer milled through $1 \mathrm{~cm}$ holes then pressed in a miniature rack and cloth press at 3000 psi for $10 \mathrm{~min}$ to obtain juice and press cake (PC). Triplicate allotments of PC (90 $\pm 5 \mathrm{~g})$ were placed into screw cap polyethylene centrifuge containers and covered with 95\% ethanol and kept at room temperature for $48 \mathrm{~h}$. Triplicate extracts were pooled, dried by rotary evaporation to remove the ethanol (Büchi rotavapor R, Brinkmann Instruments Canada Corp.; $30^{\circ} \mathrm{C}$, speed 5-7, full vacuum (-25kPa; Büchi Vac V-500) with condenser temperature of $0^{\circ} \mathrm{C}$ ), and freeze dried (Virtis 50-SRC, Gardiner, NY, USA; condenser at $-56^{\circ} \mathrm{C}$; vacuum at -100 milli-Torr; shelf at $25^{\circ} \mathrm{C}$ ) to obtain fraction FC111. Replicate PC mashes were used for one and two other extractions with 95\% ethanol, and the soluble fractions were freeze dried (fractions FC121 and FC131, respectively). Pilot-scale extraction procedures were previously described [17]. In brief, the fresh cranberries were pressed in a hydraulic rack and cloth press and the juice was separated from the PC. Following this step, the PC was covered with 95\% ethanol for $24 \mathrm{~h}$. Then, the crushed cranberries were decanted and the soluble fraction was refrigerated at $1^{\circ} \mathrm{C}$ (fraction FC111).

Phenolic acids, anthocyanins, flavonols and tartaric esters were determined by the method of Oomah et al. [22]. Antioxidant activity was measured through oxygen radical absorbance capacity (ORAC), as described previously [23]. The polyphenolics and antioxidant activities of the fresh cranberry fruit fractions obtained by pilot-scale ethanol extraction of the PC was previously reported [17]. As described, PC extracts including FC111 showed three to four times the phenolic acid, tartaric ester contents and antioxidant activities, as well as five to 10 times the flavonols and anthocyanins of their respective juice powders [17]. There was good similarity between the amounts of measured chemical constituents of laboratory- and pilot-scale preparations, as well as their antimicrobial activity (see result section).

\section{Antibiotic susceptibility testing and synergy studies}

Minimal inhibitory concentrations (MICs) of antibiotics and cranberry extracts were determined by a broth microdilution technique, following the recommendations of the Clinical and Laboratory Standards Institute [24]. A checkerboard protocol [25] was conducted by a broth microdilution method similar to that used for standard MIC determinations to evaluate the effect of varying concentrations of cranberry extracts on the activity of known antibiotics against $S$. aureus strains. The fractional inhibitory concentration (FIC) indices were calculated as follow: $\mathrm{FIC}$ index $=\mathrm{FIC}_{\mathrm{A}}+\mathrm{FIC}_{\mathrm{B}}=\mathrm{A} / \mathrm{MIC}_{\mathrm{A}}+\mathrm{B} / \mathrm{MIC}_{\mathrm{B}}$, where $\mathrm{A}$ and $\mathrm{B}$ are MICs of compounds $\mathrm{A}$ and $\mathrm{B}$ in combination, $\mathrm{MIC}_{\mathrm{A}}$ and $\mathrm{MIC}_{\mathrm{B}}$ are the MICs of compound $\mathrm{A}$ and compound $\mathrm{B}$ alone and $\mathrm{FIC}_{\mathrm{A}}$ and $\mathrm{FIC}_{\mathrm{B}}$ are the FICs of compound $\mathrm{A}$ and of compound $\mathrm{B}$. Indifference for drug interactions or an additive effect is demonstrated if the FIC index is $>0.5-4$, a synergy if the FIC index is $\leq 0.5$, whereas an antagonistic effect is represented by a FIC index of $>4$ [26].

\section{Time-kill experiments}

Time-kill experiments were performed to observe the bactericidal effect (i.e., a $3 \log 10$ reduction in CFU/mL) of cranberry extracts alone or in combination with subinhibitory concentrations (sub-MICs) of traditional antibiotics. The CAMHB medium was inoculated with $S$. aureus at $\sim 10^{5}-10^{6} \mathrm{CFU} / \mathrm{mL}$ and grown at $35^{\circ} \mathrm{C}$, with shaking $(225 \mathrm{rpm})$ in the absence or presence of tested agents at the specified concentrations (see the figure legends). At several time points, bacteria were sampled, serially diluted and plated on TSA for CFU determinations.

\section{Transcriptional profiles}

The modulation of transcriptional profiles of $S$. aureus strains ATCC 29213, MRSA N315, SHY97-4320 and SHY97-3406 by the cranberry product NC90 was first evaluated by exploratory transcriptional profiling experiments using a sub-genomic array as described previously (in detail) $[27,28]$. Bacteria $\left(\sim 10^{7}-10^{8} \mathrm{CFU} / \mathrm{mL}\right)$ were exposed to $\mathrm{NC} 90$ at the MIC (2 mg/mL) for $30 \mathrm{~min}$ in CAMHB. Culture samples $\left(\sim 10^{8}\right.$ cells) were treated with RNAprotect (Qiagen, Mississauga, ON, Canada) for at least $10 \mathrm{~min}$. Bacterial pellets were then suspended in $100 \mu \mathrm{L}$ of TE buffer containing $200 \mu \mathrm{g} / \mathrm{mL}$ lysostaphin and incubated at room temperature for $1 \mathrm{~h}$. RNA was extracted using the RNeasy Mini Kit and treated with the RNAse-free DNAse set (Qiagen). Total RNA $(2.5 \mu \mathrm{g})$ and $1 \mu \mathrm{L}$ of the appropriate RNA spike from Lucidea Universal Scorecard (GE Healthcare Life Sciences, Baie D'Urfé, QC, Canada) was reverse transcribed using $5 \mu \mathrm{g}$ of random hexamers, a dNTP mix, 5-[3-aminoallyl]-2-dUTP and the Superscript II RT (Invitrogen, Life Technologies Inc., Burlington, ON, Canada). The amino-modified cDNA was purified and labeled with NHS-Cy3 (untreated control) and -Cy5 (bioactive agent test) prior to hybridization on GAPS II slides (Corning, NY, USA). The probes (200 pmol, $\geq 8 \%$ incorporation) were suspended in $18.5 \mu \mathrm{L}$ of hybridization 
buffer (5X SSC, 0.1\% SDS, 25\% formamide, $100 \mu \mathrm{g} / \mathrm{ml}$ mouse COT1 DNA (Invitrogen)). The prehybridization, hybridization and washing steps were done as prescribed for Corning Gaps II Slides. Hybridization signals for each spot were quantified with the ScanArrayExpress Microarray Scanner and the ScanArrayExpress software V 2.2.0.0022 (Perkin Elmer, Wellesley, MA, USA). Intensity of each dye was adjusted using the signal of the control spots from Lucidea Universal Scorecard and data were submitted to the Lowess normalization. Only signals showing intensity three times above the background were analyzed as described previously $[18,27]$. Expression ratios (Cy5 [treated]/Cy3 [untreated control]) were represented in $\log 2$. Only $\log 2$ ratios with a minimum mean of $\geq 2.0$ (or $\leq-2.0$ ) obtained for at least two of the four $S$. aureus strains tested were considered. Data represent the average of triplicate spots from duplicate independent experiments for each of the four tested $S$. aureus strains. The modulation of expression of marker genes providing transcriptional signatures was thereafter confirmed by qPCR analyses.

\section{Quantitative PCR (qPCR)}

Transcriptional modulations induced by cranberry fractions and observed by using exploratory microarrays were confirmed by qPCR for a selection of marker genes and strains. Additional RNAs, from three independent bacterial cultures and prepared as described above, were obtained for qPCR analyses. The qPCR assays using SYBR green (Invitrogen) and the JumpStart Taq DNA Polymerase (Sigma) were performed as described previously [27] for the marker vraS, sgtB, murZ, mrs A, lytM and mntB genes indicative of a cell wall stress $[29,30]$. The relative expression ratios were calculated using the cycle threshold $\left(C_{\mathrm{t}}\right)$ of the untreated culture (no-bioactive agent control) and that of the housekeeping gyrA gene [n-fold expression $=2^{-\Delta \Delta C \mathrm{t}}$, where $\Delta \Delta C_{\mathrm{t}}=\Delta C_{\mathrm{t}}$ (treated culture) $/ \Delta C_{\mathrm{t}}$ (untreated culture) and $\Delta C_{\mathrm{t}}$ represents the difference between the $C_{\mathrm{t}}$ of the gene studied and the $C_{\mathrm{t}}$ of $\left.g y r A\right]$. The sequences of primers for qPCR were: $\operatorname{gyr} A$-forward $5^{\prime}$ CATTGCCAGATGTTCGTGAC $-3^{\prime}$ and $g y r A$-reverse $5^{\prime}$ CACCAACGATACGTGCTGAT -3'; vraR-forward AAA AGATATCGCCGATGCAG and vraR-reverse ATAACT CTGCCGCGCTTTTTC; sgtB-forward AAACCGCCGA AAAAGAAAAA and $s g t B$-reverse TCATCCACATTATCG CGTGT; $m s r A$-forward GCAAATGGTGTAGGTAAGA CAACT and $m s r A$-reverse ATCATGTGATGTAAACA AAAT; murZ-forward ACGCACACTAAATGGGGAAG and murZ-reverse CCTCAGCAATTAAACCAGCA; lytMforward ATTAACAGCAGCAGCGATTG and lytM-reverse TGTGCTTGTTGGGTGTTTGT; $m n t B$-forward C CTGGTGTTGCCCTATCATT and mntB-reverse GGCG TCAGGTTTCGTTTTAC.

\section{Inhibition of macromolecular biosynthesis}

Macromolecular biosynthesis assays were performed exactly as described previously [31]. Briefly, S. aureus ATCC 292123 was grown in a complete defined medium, and transferred to a round-bottom microwell plate containing radiolabeled precursors $\left[{ }^{3} \mathrm{H}\right]$-Leucine; $\left[{ }^{3} \mathrm{H}\right]$-Thymine; $\left[{ }^{3} \mathrm{H}\right]$-Uridine (Perkin Elmer, Montreal, QC, Canada) or D- $\left[{ }^{3} \mathrm{H}\right]$-Alanine (American radiolabeled chemicals, St-Louis, MO, USA), as well as various dilutions of antibiotic agents. Incorporation was allowed to proceed for 45 min (for Leu and D-Ala), or $35 \mathrm{~min}$ (for Thy and Uri) at $35^{\circ} \mathrm{C}$. The reaction was terminated by transferring the mixtures into pre-chilled trichloroacetic acid (10\% final), followed by collection of the precipitated macromolecules on GF/C filter using a dot-blot filtration system. The dried filter was cut and the level of radiolabeled precursor incorporation was determined by liquid scintillation counting. Data represent the average of three independent experiments.

\section{Mouse mastitis model of infection}

The mastitis model was previously optimized for experimental therapy [32]. CD-1 lactating mice (Charles River, St-Constant, Canada) were used 12 to 14 days after offspring birth. Pups were removed $1 \mathrm{~h}$ before intramammary inoculation, under anesthesia, of both L4 (on the left) and R4 (on the right) abdominal mammary glands with $100 \mu \mathrm{L}$ of $S$. aureus Newbould (1 CFU/ $\mu \mathrm{L})$. Glands were treated (intramammary) $4 \mathrm{~h}$ after infections with amoxicillin, a cranberry extract or a combination of both. Mice were then sacrificed $14 \mathrm{~h}$ post-treatment for mammary gland sampling, homogenization, plating, and bacterial counts. Data represent two independent experiments using several mice and glands in each.

The animal experiments were conducted following the guidelines of the Canadian Council on Animal Care. Protocol 08-FM1 was specifically approved by the institutional ethics committee on animal experimentation of the Faculté des Sciences of Université de Sherbrooke to perform the animal studies included in the present article.

\section{HPLC-MS analysis of cranberry fraction FC111}

One milligram aliquots of each dry powdered fraction were suspended in 20\% aqueous methanol, $0.1 \%$ TFA, at $1 \mathrm{mg} / \mathrm{mL}$, prior to HPLC-MS analysis. This analysis was performed on an Agilent 1100 series LC/MSD SL system (Agilent Technologies, Mississauga, ON), equipped with a quaternary pump, in-line degasser, robotic auto sampler and diode array (DAD) and single quadropole mass spectrometry (SQD) detectors. The separation and characterizations were achieved using a Zorbax Eclipse XDB-C18 (Agilent Technologies) analytical column $(4.6 \times 150 \mathrm{~mm}$, $5 \mu \mathrm{m}$ particle size) fitted with a Zorbax Eclipse XDB-C18 analytical guard column $(4.6 \times 12.5 \mathrm{~mm}, 5 \mu \mathrm{m}$ particle 
size). A tertiary solvent system was used, $(\mathrm{A}=0.1 \%$ aqueous trifluoroacetic acid; $\mathrm{B}=$ water:methanol:trifluoroacetic acid 1:1:0.1; $\mathrm{C}=$ acetonitrile), at a flow rate of $0.5 \mathrm{~mL} / \mathrm{min}$, with a column temperature of $45^{\circ} \mathrm{C}$, and $15 \mu \mathrm{L}$ sample injection volume, according to the following gradient: Time $=0 \min . \mathrm{A}: \mathrm{B}=100: 0 ;$ Time $=2 \min . \mathrm{A}: \mathrm{B}=85: 15$; Time $=20 \mathrm{~min} . \mathrm{A}: \mathrm{B}=0: 100$; Time $=26 \mathrm{~min} . \quad \mathrm{B}=100 \%$ isocratic; Time $=30 \mathrm{~min} . \mathrm{B}: \mathrm{C}=0: 100$; Time $=33 \mathrm{~min}$. $\mathrm{C}=100 \%$ isocratic; post time equilibration (3 min.) $\mathrm{A}=$ $100 \%$. The entire UV-vis absorption spectrum (190-900 $\mathrm{nm})$ was recorded, while general phenolics $(280 \mathrm{~nm})$, anthocyanins $(520 \mathrm{~nm})$, and flavonols $(360 \mathrm{~nm})$ channels were monitored. Atmospheric pressure electrospray ionization mass spectra in both positive (PIM) and negative (NIM) ion modes (PIM = 150-1400 amu; NIM = 150$2000 \mathrm{amu}$ ) were recorded on duplicate injections of the same sample (drying gas flow $10 \mathrm{~L} / \mathrm{min}$; nebulizer pressure 30 psig; dry gas temperature $350^{\circ} \mathrm{C}$; PIM capillary voltage 3000; NIM capillary voltage 3500 ). Peak identities were assigned using a combination of UV-vis absorption spectra, MS fragmentation patterns, congruent retention times with commercially available standards, and comparison to relevant cranberry literature [33-35].

\section{Statistical analysis}

Statistical analyses were carried out with the GraphPad Prism Software (v.5.00). Tests used for the analysis of each experiment are specified in the figure legends.

\section{Results}

The NC90 and the PC fraction FC111 are bactericidal and affect the transcription of genes associated with a cell wall stress

The MIC of the cranberry product NC90 against $S$. aureus ATCC 29213, Newbould and MRSA COL was $2 \mathrm{mg} / \mathrm{mL}$. In an attempt to understand the basis of the growth inhibitory effect of NC90 observed on S. aureus, we studied the modulation of bacterial gene expression for a variety of strains by microarray analyses (Table 1). Exposure of any of the four tested $S$. aureus strains (ATCC 29213, MRSA N315, SHY97-4320, SHY97-3906) to NC90 up-regulated strongly several genes involved in cell wall biosynthesis, similar to the up-regulation of genes caused by antibiotics known to disrupt peptidoglycan biosynthesis. Indeed, the strong expression of $f m t, p b p 2, m u r Z, s g t B, t c a A$ and $v r a S /$ $R$ genes is evidence of a cell wall stress induced by the tested cranberry product NC90 (Table 1). Our data are consistent with the results from other laboratories on the transcriptional profiles obtained by exposure of $S$. aureus to oxacillin, bacitracin and D-cycloserine [30] or to daptomycin and vancomycin [29] and these similarities are also reported in Table 1. NC90 also up-regulated lytM, encoding a peptidoglycan hydrolase distinctively like daptomycin (Table 1), and down-regulated genes such as spa, mntABC, isdA, hla, and femC.

To follow up, extracts from press cakes (PC) were investigated. The MIC of FC111 (lab- and pilot scale extracts) was lower than that of $\mathrm{NC} 90$ and represented $1 \mathrm{mg} / \mathrm{mL}$ against $S$. aureus ATCC 29213, Newbould and MRSA COL. Besides, the MIC value for both FC121 and FC131 was higher ( $3 \mathrm{mg} / \mathrm{mL}$ ). Since FC111 showed the lowest MIC (best efficiency), its bactericidal effect against $S$. aureus ATCC 29213 and MRSA COL was evaluated in time-kill experiments. FC111 at $1 \mathrm{mg} / \mathrm{mL}$ (MIC) induced more than a 3- $\log 10$ reduction of $\mathrm{CFU} / \mathrm{mL}$ against both strains compared to their respective untreated control cultures after $8 \mathrm{~h}$ of incubation and a concentration of $2 \mathrm{X} \mathrm{MIC} \mathrm{(2 \textrm {mg } /}$ $\mathrm{mL}$ ) yielded more than a $6-\log 10$ reduction of $\mathrm{CFU} / \mathrm{mL}$ at $8 \mathrm{~h}$ and no detectable CFU after $24 \mathrm{~h}$ (data not shown).

Subsequently, we used qPCR to first confirm the transcriptional effects induced in S. aureus ATCC 29213 following exposure to NC90 in DNA array experiments (above) and secondly, to detect similar transcriptional modulations induced by the most active ethanol-extracted PC fraction FC111. Modulation of the same cell wall stress markers (lytM, vraR, sgtB, msrA, murZ and $m n t B$ ) was indeed detected for both FC111 and NC90, indicating a similar mode of action against S. aureus (Figure 1).

\section{FC111 inhibits cell wall biosynthesis}

Whole-cell macromolecular biosynthesis assays were performed to elucidate the mechanism of action of FC111 and to confirm its inhibitory effect on cell-wall biosynthesis. S. aureus ATCC 29213 was treated with several concentrations of the cranberry fraction FC111 or known antibiotics and the percentage of incorporation of radiolabeled precursors into macromolecules was evaluated (Figure 2). All known drugs targeted the expected macromolecular biosynthesis; chloramphenicol, norfloxacin, rifampicin and vancomycin inhibited protein, DNA, RNA and cell wall biosynthesis, respectively. In the presence of $2(2 \mathrm{mg} / \mathrm{ml})$ and 4 times $(4 \mathrm{mg} / \mathrm{ml})$ the $\mathrm{MIC}$ of the cranberry fraction FC111, the incorporation of $\mathrm{D}-\left[{ }^{3} \mathrm{H}\right] \mathrm{Ala}$, a precursor of cell wall peptidoglycan, was significantly reduced compared to that observed for precursors of DNA, RNA and proteins (Figure 2E).

\section{In Vitro bactericidal effect of FC111 and $\beta$-lactam antibiotic combinations}

Since exposure of $S$. aureus to FC111 induced cell wall stress, we investigated the potential synergy between this cranberry PC fraction with amoxicillin (used for treatment of $S$. aureus-induced bovine mastitis in veterinary medicine) and oxacillin (used for many clinical indications in humans). Checkerboard assays were performed and a FIC index was determined for each tested combination against S. aureus ATCC 29213 ( $\beta$-lactam susceptible strain) and 
Table 1 Genes up- and down-regulated for at least two of four S. aureus strains following a 30-min exposure to the cranberry product $\mathrm{NC} 90(2 \mathrm{mg} / \mathrm{mL})$

\begin{tabular}{|c|c|c|c|c|c|c|c|c|c|c|}
\hline \multirow[t]{2}{*}{$\begin{array}{l}\text { ORF } \\
\text { SACOL }\end{array}$} & \multirow[t]{2}{*}{$\begin{array}{l}\text { Gene } \\
\text { name }\end{array}$} & \multirow[t]{2}{*}{ Gene annotation } & \multicolumn{4}{|c|}{ Fold expression ${ }^{a}$ for each strain } & \multirow[b]{2}{*}{ DAP $^{b}$} & \multirow[b]{2}{*}{$\operatorname{VAN}^{\mathbf{b}}$} & \multirow[b]{2}{*}{$O X A^{b}$} & \multirow[b]{2}{*}{$\mathrm{OBC}^{\mathrm{c}}$} \\
\hline & & & $\begin{array}{r}\text { ATCC } \\
29213\end{array}$ & $\begin{array}{r}\text { MRSA } \\
\text { N315 }\end{array}$ & $\begin{array}{r}\text { SHY97 } \\
4023\end{array}$ & $\begin{array}{r}\text { SHY97 } \\
3906\end{array}$ & & & & \\
\hline
\end{tabular}

Up-regulated genes

$\begin{array}{lll}0263 & & \text { Peptidoglycan hydrolase } \\ 1066 & \text { fmt } & \text { Fmt protein } \\ 1459 & & \text { Methionine sulfoxide reductase } \\ 1490 & \text { pbp2 } & \text { Penicillin binding protein 2 } \\ 1777 & \text { htrA } & \text { Putative serine protease Htra } \\ 1932 & & \text { Transglycosylase domain protein } \\ 1942 & \text { vraR } & \text { DNA-binding response regulator } \\ 1943 & \text { vraS } & \text { Sensor histidine kinase VraS } \\ 1944 & & \text { Hypothetical protein } \\ 2017 & \text { groES } & \text { Chaperonin } \\ 2116 & \text { murAB } & \text { UDP-N-AcGlc-1-carbotransferase } \\ 2291 & & \text { Staphyloxanthin biosynthesis } \\ 2352 & \text { tcaA } & \text { TcaA protein } \\ 2584 & \text { isaA } & \text { Immunodominant antigen A }\end{array}$

Down-regulated genes

\begin{tabular}{|c|c|c|c|c|c|c|c|c|}
\hline 0095 & spa & IgG binding protein & -33.3 & -2.0 & -37.5 & nd & - & $=$ \\
\hline 0096 & sars & Accessory regulator & -2.0 & -2.9 & -2.7 & -2.2 & - & - \\
\hline $0136-0150^{e}$ & capA-O & Capsular polysaccharide & -4.9 & nd & -3.1 & -1.9 & - & $=$ \\
\hline 0317 & & Lipase precursor & -8.6 & -6.8 & -4.1 & -1.7 & - & - \\
\hline $451-452^{\mathrm{e}}$ & ahpFC & Alkyl hydroperoxide reductase & -3.4 & -3.6 & -8.2 & -1.2 & $=$ & $=$ \\
\hline 0679 & & $\mathrm{Na}+/ \mathrm{H}+$ antiporter, $\mathrm{MnhA}$ & -4.5 & -10.0 & -13.0 & -25.0 & $=$ & $=$ \\
\hline $0688-0690^{e}$ & mntABC & $\mathrm{ABC}$ transporter & -43.5 & -66.7 & -86.7 & -91.7 & - & $=$ \\
\hline $0765-0766^{e}$ & saeSR & Sensor/Histidine kinase & -1.5 & -3.7 & -1.5 & -3.6 & $=$ & $=$ \\
\hline 1072 & folD & THF dehydrogenase & -2.1 & -2.6 & -2.7 & nd & $=$ & $=$ \\
\hline 1079 & purF & amidophosphoribosyltransferase & nd & -10.0 & -0.8 & -2.6 & $=$ & - \\
\hline 1140 & isdA & Heme-iron transport & -5.3 & -2.1 & -2.9 & nd & - & $=$ \\
\hline $1158-1160^{\mathrm{e}}$ & $\operatorname{sdh} A B C$ & Succinate dehydrogenase & -5.1 & -7.9 & -4.5 & -3.8 & - & - \\
\hline 1173 & hla & Alpha-hemolysin & -3.6 & -4.3 & nd & -2.6 & - & $=$ \\
\hline $1262-1263^{e}$ & sucCD & Succinyl-CoA synthetase & -5.6 & -3.1 & -6.4 & -2.3 & $=$ & $=$ \\
\hline 1328 & $g \ln R$ & Glutamine synthetase repressor & -3.7 & -6.3 & -3.4 & -5.3 & - & - \\
\hline 1329 & femC & Glutamine synthetase FemC & -2.7 & -4.2 & -3.2 & -2.9 & - & $=$ \\
\hline 1368 & katA & Catalase & -3.2 & -2.4 & -5.2 & -2.1 & $=$ & + \\
\hline 1385 & $\operatorname{acn} A$ & Aconitate hydratase & -3.4 & -3.0 & -6.3 & nd & $=$ & $=$ \\
\hline 1396 & fmtC & FmtC protein & -0.9 & -2.4 & -2.0 & nd & - & - \\
\hline $1448-1449^{e}$ & SUCAB & 2-oxoglutarate dehydrogenase & -8.1 & -5.4 & -4.8 & -4.9 & $=$ & $=$ \\
\hline 1741 & $i c d$ & Isocitrate dehydrogenase, NADP & -5.6 & -2.2 & -11.5 & -2.5 & $=$ & $=$ \\
\hline 1742 & $g t / A$ & Citrate synthase & -6.7 & -2.3 & -14.3 & -2.2 & $=$ & $=$ \\
\hline 1743 & & Amino acid permease & -3.1 & -1.2 & -4.8 & -1.5 & $=$ & $=$ \\
\hline 2055 & rsbW & Anti-sigma B factor & -2.6 & nd & -1.6 & -2.1 & - & $=$ \\
\hline
\end{tabular}


Table 1 Genes up- and down-regulated for at least two of four S. aureus strains following a 30-min exposure to the cranberry product $\mathrm{NC90}(2 \mathrm{mg} / \mathrm{mL})$ (Continued)

\begin{tabular}{|c|c|c|c|c|c|c|c|c|c|}
\hline 2057 & rsbu & Sigma factor B regulator protein & -1.3 & -3.1 & -0.9 & -2.1 & $=$ & $=$ & - \\
\hline $2066-2068^{e}$ & $k d p A B C$ & Potassium-transporting ATPase & -3.5 & nd & -2.3 & -1.7 & $=$ & $=$ & $=$ \\
\hline 2293 & & NAD/NADP dehydrogenase & -2.0 & -2.4 & -1.3 & nd & - & $=$ & - \\
\hline 2694 & geh & lipase & -27.3 & -4.3 & -20.0 & nd & $=$ & $=$ & $=$ \\
\hline
\end{tabular}

${ }^{a}$ Data are expressed in log2 ratios of Cy5(cranberry-treated)/Cy3(untreated control); see material and methods.

${ }^{b} \mathrm{Up}(+)$ or down (-) expression of the indicated gene by exposure to daptomycin (DAP), vancomycin (VAN) or oxacillin (OXA), as reported by Muthaiyan et al. [29]; the equal sign (=) indicates genes that were not affected.

' Up (+) or down (-) expression of the indicated gene by exposure to oxacillin (O), bacitracin (B) and D-cycloserine (C) as reported by Utaida et al. [30]; the equal sign (=) indicates genes that were not affected.

$\mathrm{d}$ The plus sign (+) indicates genes known to be regulated by the two-component response regulator VraSR following a cell wall stress [42].

e To avoid repetition, the fold modulation of genes arranged in operons is represented as an average for the indicated gene set.

MRSA COL (with the mecA/PBP2A-mediated $\beta$-lactam resistance). The cranberry fraction FC111 increased the inhibitory activity of amoxicillin and oxacillin against both tested $S$. aureus strains by triggering up to 512 -fold reductions in $\beta$-lactam MIC values (Table 2). Combination of FC111, 128 or $256 \mu \mathrm{g} / \mathrm{mL}$ (i.e., $1 / 8$ or $1 / 4$ FC111 MIC, respectively), with either of the $\beta$-lactams yielded FIC indices of $\leq 0.25$, for each of the strains tested. These FIC indices clearly showed synergy between FC111 and $\beta$-lactams against $S$. aureus. Data also demonstrated that this synergy can efficiently bypass the mecA-mediated mechanism of $\beta$-lactam resistance found in MRSA strain COL.

The synergistic effect arising from the combination of $\beta$-lactams and FC111 in checkerboard assays was explored in greater details by using kill kinetic studies. Combination of the cranberry fraction FC111 at its MIC $(1 \mathrm{mg} / \mathrm{mL})$ and $1 / 8 \times$ MIC of amoxicillin induced a strong bactericidal effect $(>3 \log 10 \mathrm{CFU} / \mathrm{mL})$ against a bovine mastitis strain (S. aureus Newbould, also used in our mastitis model of infection in the mouse [see below]) compared to the bactericidal effect observed with FC111

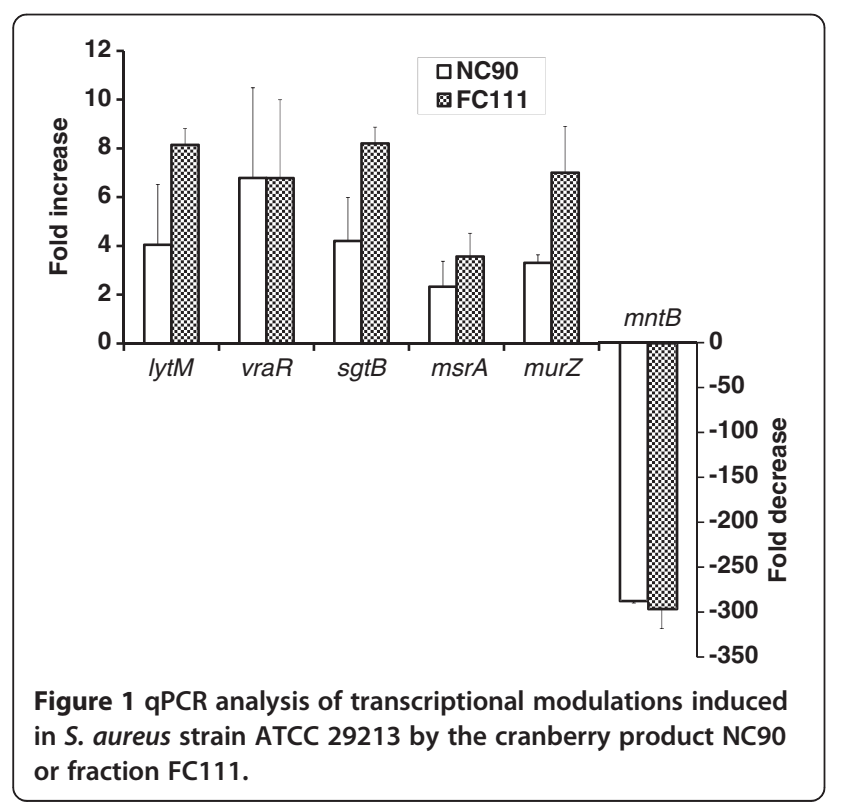

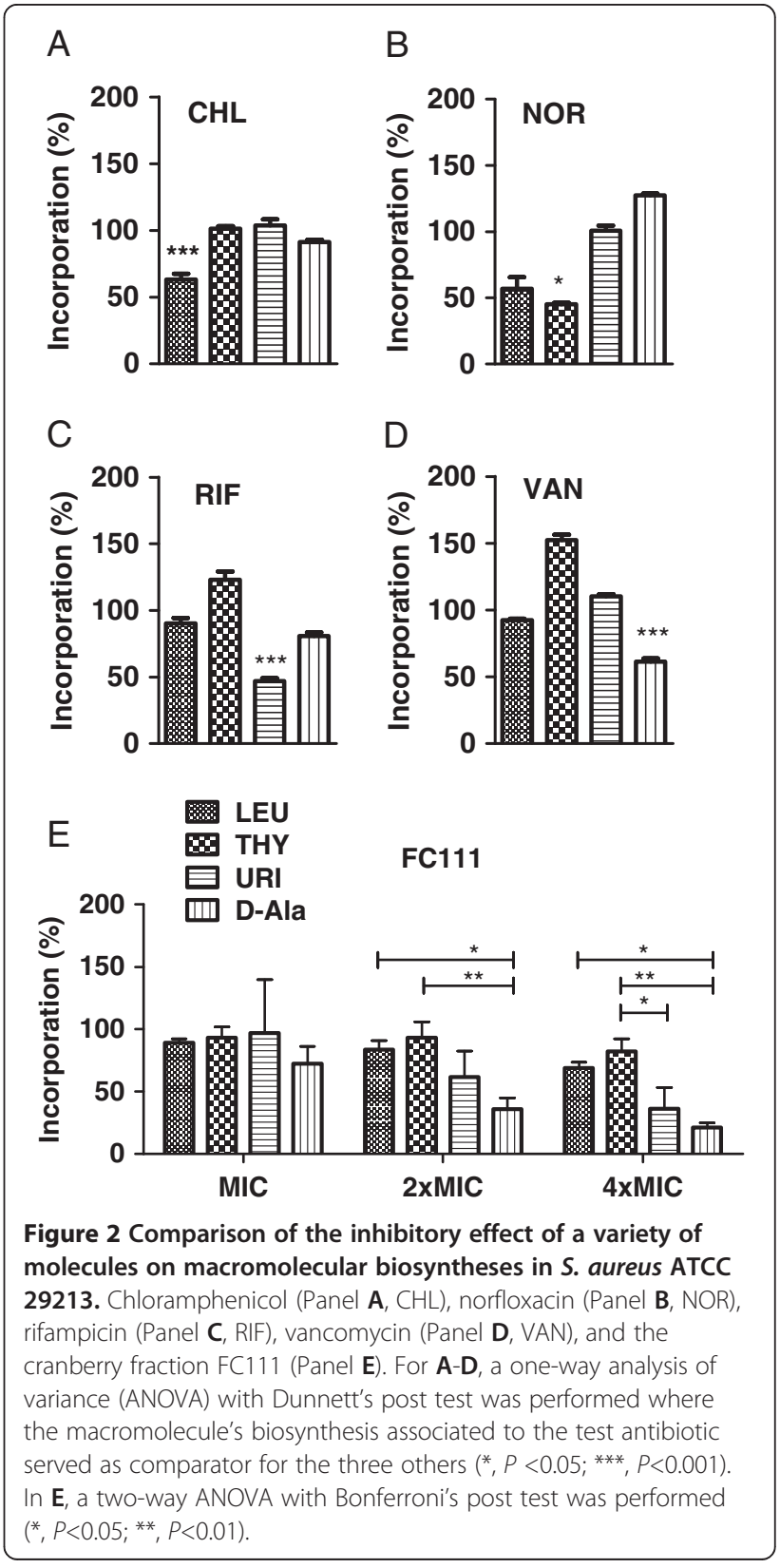


Table 2 Minimal inhibitory concentrations (MIC) of amoxicillin and oxacillin alone or in combination with increasing concentrations ( 0 to $256 \mu \mathrm{g} / \mathrm{ml}$ ) of the cranberry PC fraction FC111 against S. aureus ATCC 29213 and MRSA COL

\begin{tabular}{|c|c|c|c|c|c|c|}
\hline \multirow[t]{2}{*}{ S. aureus strains } & \multirow[t]{2}{*}{ Antibiotic } & \multicolumn{5}{|c|}{$\begin{array}{l}\text { MIC of antibiotic in } \mu \mathrm{g} / \mathrm{mL} \text { in the presence of an increasing concentration of the cranberry fraction FC111, } \\
\text { also in } \mu \mathrm{g} / \mathrm{mL} \text { (fold decrease in antibiotic MIC) }{ }^{\mathrm{a}}\end{array}$} \\
\hline & & 0 & 32 & 64 & 128 & 256 \\
\hline ATCC 29213 & amoxicillin & 0.06 & $0.06(1 \times)$ & $0.06(1 \times)$ & $0.015(4 \times)$ & $0.015(4 \times)$ \\
\hline MRSA COL & & 512 & $4(128 x)$ & $4(128 x)$ & $1(512 \times)$ & $1(512 \times)$ \\
\hline ATCC 29213 & oxacillin & 0.5 & $0.06(8 x)$ & $0.03(16 x)$ & $0.03(16 \times)$ & $0.03(16 \times)$ \\
\hline MRSA COL & & 512 & $256(2 x)$ & $128(4 \times)$ & $32(16 \times)$ & $16(32 x)$ \\
\hline
\end{tabular}

${ }^{a}$ Combination of 128 or $256 \mu \mathrm{g} / \mathrm{mL}$ of $\mathrm{FC} 111$ with either antibiotic yielded FIC indices of $\leq 0.25$ against all tested strains.

or amoxicillin alone (Figure 3A). Moreover, the combination of FC111 at its MIC and oxacillin $(1 / 512 \times$ MIC) also showed strong bactericidal effect against $S$. aureus MRSA COL (Figure 3B).

\section{The FC111-amoxicillin combination improves bacterial clearance in mammary glands}

The in vivo relevance of the synergy between the cranberry extract FC111 with $\beta$-lactams was determined using a mouse mastitis model. The mice were infected with the bovine strain $S$. aureus Newbould and treated with FC111, amoxicillin or a combination of both (Figure 4). Compared to the untreated mice, there was no significant change in bacterial loads (CFU/g of gland) when mice were treated with either one of the compounds. However, a significant reduction in bacterial counts $(1.8 \mathrm{Log} 10 \mathrm{CFU} / \mathrm{g}$ of gland) was observed using the FC111-amoxicillin combination.

\section{HPLC-MS analysis of cranberry fraction FC111}

HPLC-MS was performed on laboratory-scale cranberry fraction FC111, which had the following spectrophotometrically measured [22] classes of chemical compounds per gram of freeze-dried powder: 132.4 (total phenolics), 8.3 (tartaric esters), 9.6 (flavonols) and 23.8 (anthocyanins) mg equivalents of catechin, caffeic acid, quercetin and cyanidin-3-glucoside, respectively. The total phenolics, tartaric esters and flavonols compared well with the composition of the pilot scale sample FC111 [17]. Laboratory- and
A

$$
\begin{aligned}
& \text { - CTRL } \\
& \text { — AMO (1/8 x MIC) } \\
& \text { - AMO (1/8 } \mathrm{MIC})+\mathrm{FC} 111(\mathrm{MIC}) \\
& \text { * FC111 (MIC) }
\end{aligned}
$$

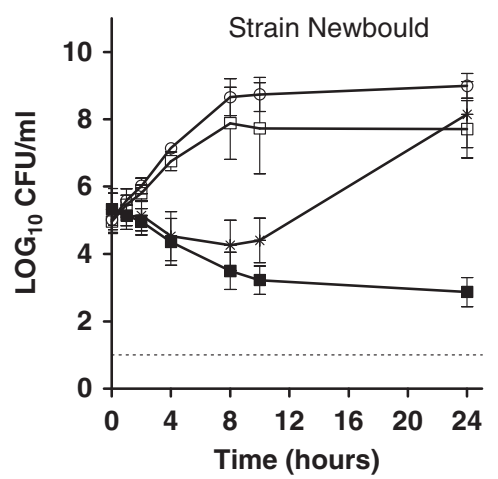

B
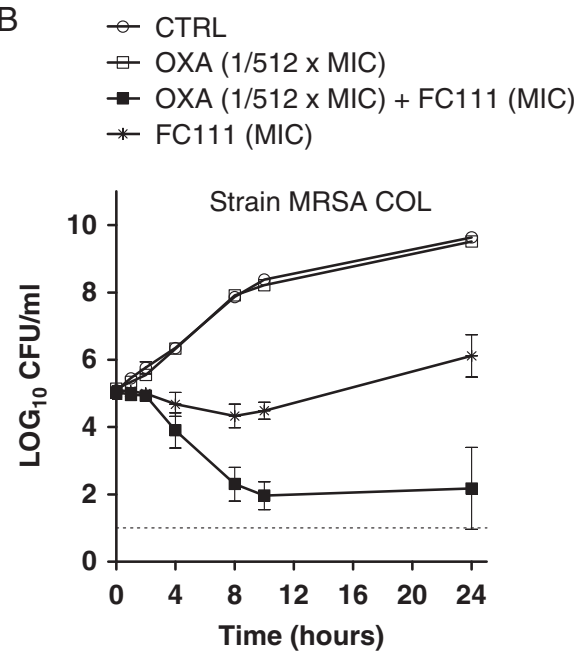

Figure 3 S. aureus kill-curve kinetics evaluated in cation-adjusted Mueller Hinton broth containing FC111 alone or in combination with the specified antibiotic. Panel $\mathbf{A}, \mathrm{FC} 111$ alone (at its MIC, $1 \mathrm{mg} / \mathrm{mL})$ or in combination with a sub-MIC $(1 / 8 \times \mathrm{MIC})$ of amoxicillin against S. aureus strain Newbould, and Panel B, with a sub-MIC (1/512 x MIC) of oxacillin against MRSA COL. Values are means of duplicates of two separate experiments. Bars represent standard deviations (SD). 


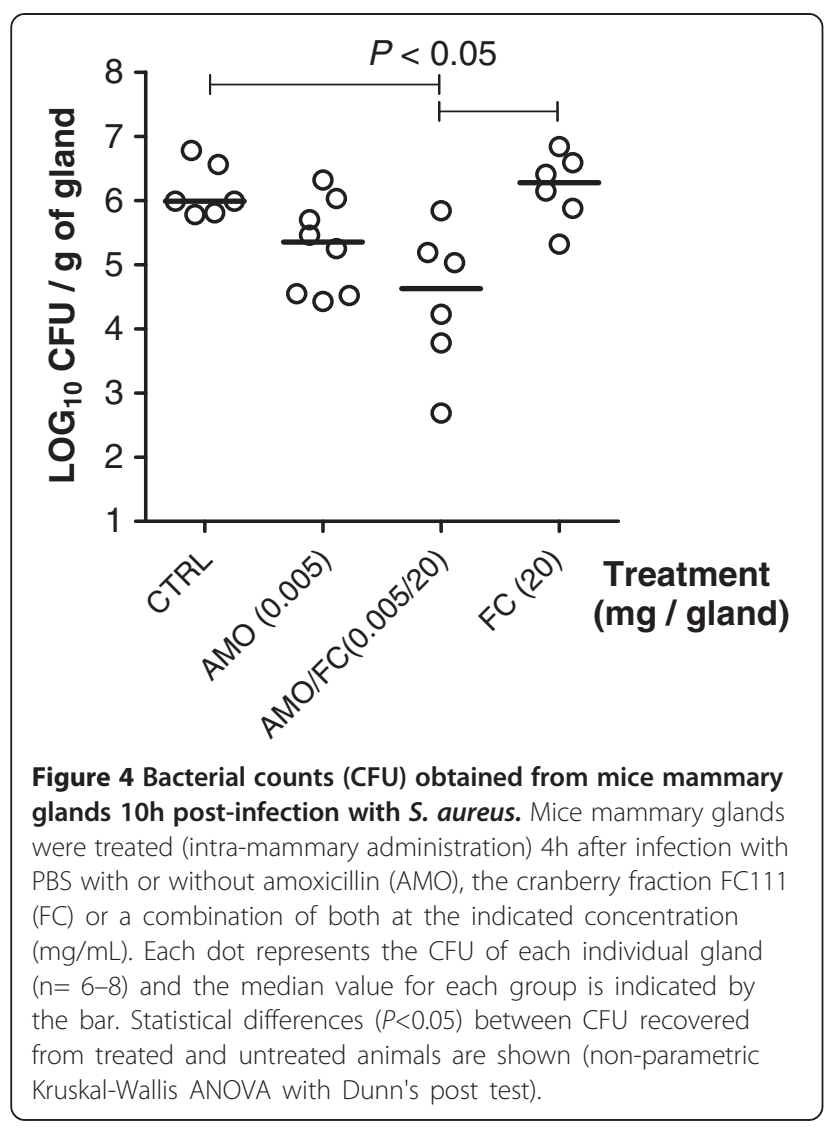

pilot-scale prepared FC111 provided identical antibacterial activity against $S$. aureus strains as reported above. HPLC separation of cranberry fraction FC111 constituents was achieved in less than $30 \mathrm{~min}$, using the program described above. A typical chromatographic trace, recorded at $254 \mathrm{~nm}$ from laboratory scale FC111 (Figure 5), demonstrates the separation of iridoids, hydroxybenzoic acid, hydroxycinnamic acid, anthocyanin and flavonol components (Table 3). Compounds lacking UV-absorbing chromophores (sugars, small organic acids etc.) were omitted from analysis. In fraction FC111, qualitatively representative of all PC extracts, the principal components were anthocyanins, peaks 21, 24-29, 31, 33 (40\%), flavonols, peaks $30-32,34-44$ (25\%), iridoids, peaks $2 \mathrm{a}, \mathrm{b}, 3,16 \mathrm{~b}$ (22\%), and the conjugated glycosides of simple phenolic acids, peaks 4-15, 16a, 17-19 (9\%), based on integrated peak areas recorded at $254 \mathrm{~nm}$ measured against total absorbance. Absolute quantification of peaks (mass balance) could not be measured, due to lack of analytical standards. Relative abundances between classes of molecules were calculated however, using integral values measured at $254 \mathrm{~nm}$, while specific wavelengths were used to compare individual compounds within a class; 520, 360, and $280 \mathrm{~nm}$ for anthocyanins, flavonols and phenolics, respectively (Table 3 , peak identities). The primary anthocyanins present were peonidin-3-O-galactoside (peak 28, $43 \%$ abundance), cyanidin-3-O-galactoside (peak 24, 18\% abundance) and peonidin-3-O-arabinoside (peak 31, 15\% abundance) (Table 3, abundances).

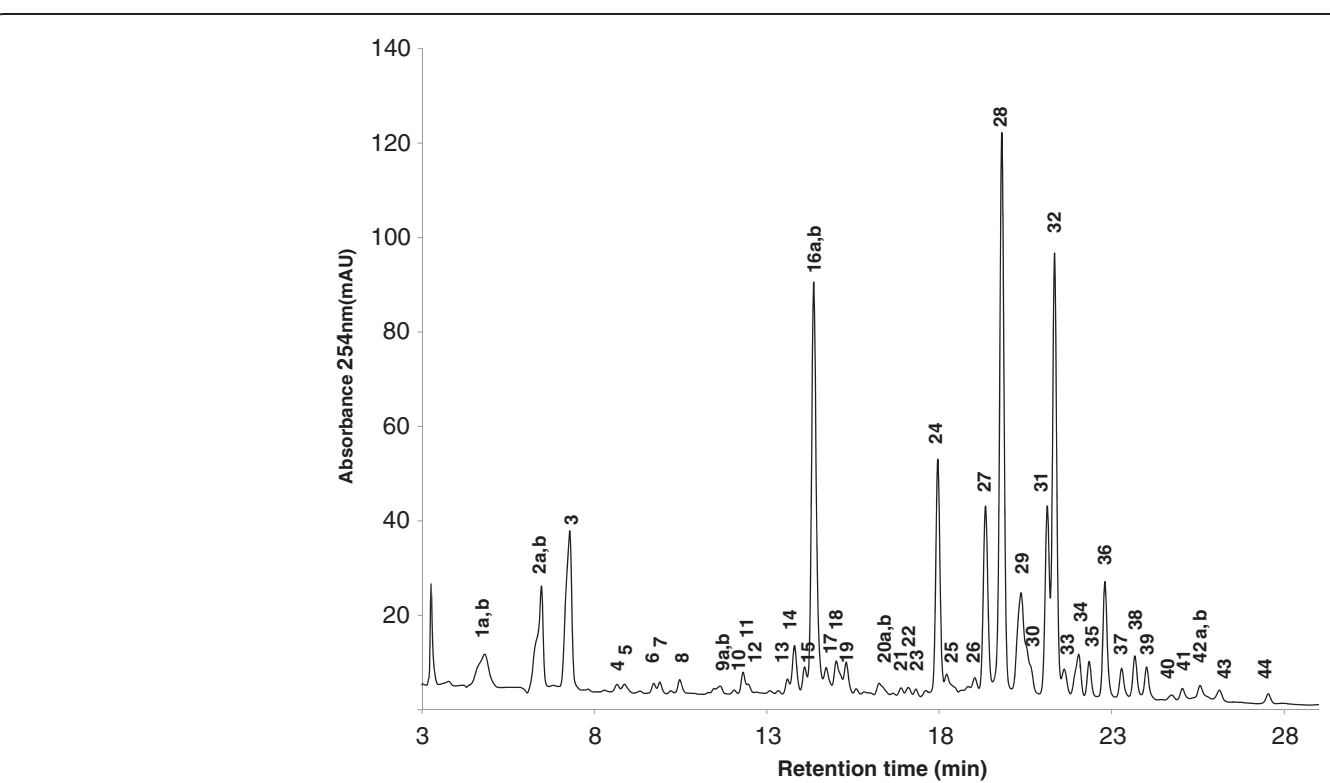

Figure 5 C18 reversed-phase HPLC chromatogram of laboratory scale fraction FC111, displaying separation of 44 constituents.

Retention time is in minutes, and absorbance measured at $254 \mathrm{~nm}$ (mAU). Alpha numeric labels refer to peaks discussed in the main text, and summarized in Table 3. 
Table 3 Laboratory scale cranberry fraction FC111 constituents separated and characterized by HPLC-DAD-MS.

\begin{tabular}{llll}
\hline Peak & $\mathbf{t}_{\mathbf{R}}(\mathbf{m i n})^{\mathbf{a}}$ & $\lambda_{\mathbf{m a x}}(\mathbf{n m})^{\mathbf{b}}$ & $\mathbf{M W}(\mathbf{D})$ \\
\hline $1 \mathrm{a}, \mathrm{b}$ & 4.8 & & 192 \\
Iridoids & & & \\
$2 \mathrm{a}, \mathrm{b}$ & 6.5 & 235 & 390 \\
3 & 7.3 & 235 & 392 \\
$16 \mathrm{~b}$ & 14.4 & 235 & 416
\end{tabular}

\section{Monophenolic acids}

$\begin{array}{llll}4 & 8.7 & 280 & 220 \\ 5 & 8.9 & 280 & \\ 6 & 9.7 & 290 & 162 \\ 7 & 9.8 & 290 & \\ 8 & 10.4 & 275 & 316 \\ 9 a, b & 11.6 & 285,320 & 342 \\ 10 & 12.0 & 275 & 300 \\ 11 & 12.3 & 295,305 & 326 \\ 12 & 12.4 & 275 & 238 \\ 13 & 13.6 & 315 & 326 \\ 14 & 13.8 & 285,310 & 326 \\ 15 & 14.1 & 295,325 & \\ 16 a & 14.4 & 280 & 284 \\ 17 & 14.7 & 285,330 & 356 \\ 18 & 15.0 & 275 & 386 \\ 19 & 15.3 & 280,330 & \\ 20 a, b & 16.3 & 280 & \end{array}$

\section{Anthocyanins}

$\begin{array}{llll}21 & 16.8 & 525 & 465 \\ 24 & 18.0 & 518 & 449 \\ 25 & 18.2 & 525 & 435 \\ 26 & 19.0 & 515 & 433 \\ 27 & 19.3 & 520 & 419 \\ 28 & 19.8 & 520 & 463 \\ 29 & 20.4 & 524 & 493 \\ 31 & 21.1 & 521 & 433 \\ 33 & 21.6 & 530 & 463\end{array}$

\section{Flavonols}

$\begin{array}{llll}30 & 20.5 & 370 & 450 \\ 32 & 21.3 & 360 & 464 \\ 34 & 22.0 & 354 & 434 \\ 35 & 22.3 & 352 & 434 \\ 36 & 22.8 & 354 & 434 \\ 37 & 23.3 & 352 & 448 \\ 38 & 23.6 & 356 & 478\end{array}$

quinic acid

monotropein

6,7-dihydromonotropein

unknown monotropein derivative

Total (vs. A254 nm)

Relative abundance $^{\mathrm{d}}$

unknown benzoic acid derivative

unknown benzoic acid derivative

unknown benzoic acid derivative

unknown benzoic acid derivative

dihydroxybenzoic acid glycoside

caffeic acid glycoside

hydroxybenzoic acid glycoside

coumaric acid glycoside isomer 1

unknown benzoic acid derivative

coumaric acid glycoside isomer 2

coumaric acid glycoside isomer 3

unknown hydroxycinnamic acid

benzoyl-glycoside

ferulic acid-glycoside

unknown benzoic acid derivative

sinapinic acid-glycoside

unknown benzoic acid derivative

Total (vs. A254 nm)

$18.5 \pm 0.78 \%$

$26.8 \pm 0.07 \%$

$54.8 \pm 0.99 \%$

$22 \%$

$$
\begin{gathered}
3.1 \pm 0.51 \% \\
0.52 \pm 0.06 \% \\
0.78 \pm 0.10 \% \\
1.18 \pm 0.11 \% \\
3.45 \pm 0.29 \% \\
3.06 \pm 0.45 \% \\
0.72 \pm 0.16 \% \\
14.04 \pm 0.49 \% \\
1.45 \pm 0.049 \% \\
15.1 \pm 0.40 \% \\
16.1 \pm 0.56 \% \\
7.22 \pm 0.092 \% \\
5.44 \pm 0.89 \% \\
5.59 \pm 0.21 \% \\
13.24 \pm 0.13 \% \\
7.47 \pm 0.28 \% \\
1.50 \pm 0.69 \%
\end{gathered}
$$

$9 \%$

$$
\begin{gathered}
0.40 \pm 0.00 \% \\
18.4 \pm 0.01 \% \\
0.60 \pm 0.03 \% \\
0.28 \pm 0.00 \% \\
11.2 \pm 0.00 \% \\
43.3 \pm 0.03 \% \\
7.64 \pm 0.00 \% \\
15.5 \pm 0.01 \% \\
1.79 \pm 0.00 \% \\
40 \%
\end{gathered}
$$

myricetin-3-O-arabinoside

$4.05 \pm 0.34 \%$

$50.2 \pm 0.11 \%$

$7.71 \pm 0.00 \%$

$3.72 \pm 0.02 \%$

$13.65 \pm 0.12 \%$

$2.87 \pm 0.01 \%$

$5.31 \pm 0.04 \%$ 
Table 3 Laboratory scale cranberry fraction FC111 constituents separated and characterized by HPLC-DAD-MS. (Continued)

\begin{tabular}{|c|c|c|c|c|c|}
\hline 39 & 24.0 & 360 & 508 & syringetin-3-O-galactoside & $4.70 \pm 0.05 \%$ \\
\hline 40 & 24.7 & 360 & & unknown flavonol derivative & $0.46 \pm 0.02 \%$ \\
\hline 41 & 25.0 & 355 & 448 & isorhamnetin-3-O-arabinoside & $1.55 \pm 0.01 \%$ \\
\hline $42 a, b$ & 25.6 & 355 & 610 & quercetin-3-O-(6"coumaroyl)-galactoside & $2.27 \pm 0.04 \%$ \\
\hline 43 & 26.1 & 355 & 478 & syringetin-3-O-arabinoside & $2.04 \pm 0.04 \%$ \\
\hline \multirow[t]{2}{*}{44} & 27.5 & 356 & 568 & quercetin-3-O-(6" benzoyl)-galactoside & $1.48 \pm 0.02 \%$ \\
\hline & & & & Total (vs. A254 nm) & $25 \%$ \\
\hline
\end{tabular}

\footnotetext{
${ }^{a}$, retention time of peak (measured in minutes).

${ }^{\mathrm{b}} \lambda \mathrm{max}$, refers to characteristic UV-VIS absorption maxima $(\mathrm{nm})$ pertinent to identification.

c MW, molecular weight (measured in Daltons).

d Relative abundance reported as percentage with associated standard deviation (based on two separate HPLC runs); iridoids calculated vs. $254 \mathrm{~nm}$; monophenolic acids calculated vs. $280 \mathrm{~nm}$; anthocyanins calculated vs. $520 \mathrm{~nm}$; flavonols calculated vs. $360 \mathrm{~nm}$.
}

\section{Discussion}

The outbreak of multidrug resistant bacteria arose from several factors, including the lack of novelty in the pipeline of drug discoveries since the 1980s, and the large and nonadequate administration of antibiotics $[7,36]$. To eradicate this problem, explorations of new sources of antimicrobial compounds, and/or finding ways to strengthen the action of well-known antibiotics are needed [31,37]. For many decades, cranberry juice and extracts have been studied for their antimicrobial potential against bacterial pathogens. Cranberry constituents are known to exert anti-adhesion and antimicrobial activities against several pathogenic bacteria and have been suggested to prevent urinary tract infections caused by uropathogenic P-type Escherichia coli [38-40]. However, the mechanisms supporting the diverse effects of cranberry on microbes are poorly understood. In this study, we produced cranberry extracts by mechanical and ethanol extraction, investigated the antibacterial modes of action of these extracts by transcriptional and macromolecular biosynthesis analyses, and assessed their in vitro and in vivo bactericidal activities.

In an attempt to investigate the mode of action of the cranberry product $\mathrm{NC} 90$, we initiated the study by performing an exploratory transcriptional analysis by microarray, which yielded the identification of several bacterial genes known to be up-regulated in the presence of cell-wall acting antibiotics, such as oxacillin, vancomycin and daptomycin [29,30,41]. Also, the cell wall stress stimulon we observed correlated well to the list of VraS/Rregulated genes known to be up-regulated in response to the inhibition of cell wall biosynthesis [42], as reported in Table 1. Interestingly, the cranberry PC extract FC111 showed a slightly lower MIC than the commercial preparation NC90 against $S$. aureus, indicating enrichment in some antibacterial compounds in FC111. In addition, qPCR analysis of key cell wall stress markers ( $\mathrm{raR} / \mathrm{S}$, $\operatorname{sgt} B$, $m s r A$, murZ) revealed similar gene expression modulations by both $\mathrm{NC90}$ and the fraction FC111, indicating that the growth inhibitory compounds remaining in FC111 should be responsible for the cell wall stress observed following exposure of $S$. aureus to this extract.

Although oxacillin, vancomycin and daptomycin disrupt cell wall peptidoglycan synthesis, these antibiotics act in different ways $[29,43]$. In the present study, it was interesting to observe that NC90 and FC111 also modulated the expression of lytM and the mntABC operon reacting to membrane depolarization, as distinctively reported for daptomycin by Muthaiyan et al. [29]. This may indicate that NC90 and the cranberry extract FC111 induce $S$. aureus membrane depolarization, as that observed after exposure to daptomycin. The gene modulations induced by cranberry also support the $S$. aureus cell disruption reported by $\mathrm{Wu}$ et al. [20], while, scanning electron microscopy of MRSA after treatment with cranberry proanthocyanidins induced negligible effect on cell morphology [44].

The action of our cranberry extract on cell wall biosynthesis was also confirmed by macromolecular biosynthesis assays in which incorporation D-Ala into cell wall materials was most affected. Hence, it was therefore tempting to conduct synergy assays with other cell-wall active antibiotics. Because $\beta$-lactams are widely used in human and veterinary medicine and because their activity is often impaired by bacterial mechanisms of resistance such as the presence of $\beta$-lactamases or the mecA gene in MRSA strains, we estimated that such a class of antibiotic compounds may greatly benefit from the action of cranberry in a variety of clinical applications. Our results showed that the combination of FC111 and amoxicillin or oxacillin used at sub-MICs, is highly bactericidal against either $\beta$-lactam-susceptible or -resistant MRSA strains. Moreover, this synergy was proven effective in a murine model of $S$. aureus-induced mastitis.

Resistance is part of the microbial evolution process and the use of antibiotics in human or animals applies a 
selective pressure favoring resistance to emerge. We did indeed report the presence of multi-antibiotic-resistant bacteria in animal food production $[45,46]$. In order to reduce antibiotic use, which could help break down emergence of antibiotic resistance in conventional and organic animal production, several alternatives to antibiotics have been investigated although none of these alternatives was proven to be as efficient as antibiotics $[47,48]$. We previously suggested that cranberry fruit derivatives could be developed to improve health and on-farm food safety while reducing the use of antibiotics as growth promoters [19]. It was recently suggested that fruit pomace can be utilized as a good source of inexpensive antioxidants for improving human health and reducing the risks of some chronic diseases [49]. Recently, we showed that our FC111 fraction from cranberry pomace (press cake) is an excellent natural polyphenolics product with increased antioxidant and vasorelaxant benefits [17]. In the present study, we demonstrated that this FC111 fraction may be developed as a viable alternative to traditional antibiotics or at least to significantly potentiate their activities against multidrug resistant bacteria such as MRSA, and thus, to significantly reduce the amounts of antibiotics required.

The cranberry fruit is rich in polyphenols, specifically anthocyanins, flavonols and flavan3-ols, which often form oligomeric and polymeric structures, along with lesser amounts of benzoic acid derivatives. These natural compounds in cranberry are often collectively referred to as tannins, which are found in abundance among many plants including berries, leaves, bark and roots. Tannins have many biological activities and flavonoids, including anthocyanins and proanthocyanidins, are believed to be the major antimicrobial components [50]. Here, the relative abundances of constituents from fraction FC111 are described in Table 3 . The primary anthocyanins present were peonidin-3-O-galactoside, cyanidin-3-O-galactoside and peonidin-3-O-arabinoside. Malvidin-3-O-galactoside and 3-O-arabinoside were also present, consistent with previously reported literature for both fresh cranberry fruit and juice extracts $[33,34]$. The dominant flavonol was quercetin-3-O-galactoside (peak 32, $50 \%$ abundance), followed by three different quercetin-3O-pentosides (peaks 34, 35, 36), totaling 25\% abundance). While commercial standards were not available for the absolute confirmation of these pentosides, they have been tentatively identified as quercetin-3-O-xyloside, quercetin-3-O-arabinofuranoside, and querecetin-3-O-arabinopyranoside, as previously reported by Borges et al. [33]. Additionally, numerous early eluting peaks (8-16 min) were detected, with absorption wavelength maxima characteristic of benzoic acids $(\lambda \max \sim 280 \mathrm{~nm})$ and hydroxycinnamic acids $(\lambda \max \sim 315 \mathrm{~nm}$ ) (Table 3 ), also consistent with previously reported literature [33,34]. Characteristic mass spectra for both parent and fragment ions indicates a number of these simple phenolic acids are linked to hexose sugars, but the absolute identity, galactose versus glucose sugar, or exact $\mathrm{O}$-linkage position could not be determined using HPLC-MS methods alone.

From our analysis of the constituents of laboratoryscale fraction FC111, it is unclear, at this point, whether the observed antibacterial activity stems from iridoids, phenolics or flavonoid components, with further isolation and characterization remaining an active area of research. However, the mechanisms of action of our FC111 fraction seem not to be related to its acidic constituents, which negatively impact bacterial proteins and DNA/ RNA syntheses [51]. Bactericidal activity of lab-prepared cranberry proanthocyanidins has been reported against MRSA [44]. Proanthocyanidin peaks could not be conclusively identified, based upon the HPLC-MS-conditions used. It is possible that the ethanolic PC extraction may not have been optimal for the solubilization of proanthocyanidins, which are generally extracted with more apolar solvents such as acetone. Given their low (essentially non-abundance) in the extracts studied herein, proanthocyanidins are not expected to play a major role in the observed biological effects, unless extraordinarily active at minute concentrations. Demonstrating novel antibacterial activity from cranberries not associated with proanthocyanidin components is especially exciting, and warrants further investigation.

\section{Conclusions}

Our study explored the mechanism of action of cranberry on $S$. aureus and revealed an antibacterial action associated with the disruption of cell wall biosynthesis similar to other known cell-wall acting antibiotics. Moreover, our results showed the potential therapeutic use of a combination of $\beta$-lactams and an easily prepared cranberry extract against S. aureus infections such as bovine mastitis.

\section{Competing interests}

The authors declare that they have no competing interests. Also note that Decas Botanical Synergies, the manufacturers of NC90, played no role in the design, implementation, analysis, or financing of this study.

\section{Authors' contributions}

$\mathrm{SB}, \mathrm{EB}, \mathrm{MG}, \mathrm{GB}, \mathrm{HR}$, JH and JM carried out the experiments. MSD, BDO, SB, $E B, M G, J H$ and FM designed and conceived the study. MSD, DBO, SB, JH and FM wrote the paper. All authors read and approved the final manuscript.

\section{Acknowledgements}

This work was supported by research grant 89758-2010 from the Natural Sciences and Engineering Research Council of Canada (NSERC) to FM and by financial support (\#1381) from Agriculture and Agri-Food Canada to MSD. We thank Decas Botanical and V. Brookes (PARC, Agassiz) for providing the cranberry extract NC90 and fresh cranberry fruits. We acknowledge technical supports by A. Campbell, E. Fan and K. Jassmann.

\section{Author details}

${ }^{1}$ Pacific Agri-Food Research Center, Agriculture and Agri-Food Canada, Agassiz, BC V0M 1A0, Canada. ${ }^{2}$ Pacific Agri-Food Research Centre, Agriculture and Agri-Food Canada, Summerland, BC VOH 1Z0, Canada. ${ }^{3}$ Crops and Livestock Research, Agriculture and Agri-Food Canada, Charlottetown, PE 
C1A 4N6, Canada. ${ }^{4}$ Département de Biologie, Centre d'Étude et de Valorisation de la Diversité Microbienne (CEVDM), Faculté des Sciences, Université de Sherbrooke, Sherbrooke, QC J1K 2R1, Canada.

Received: 22 October 2012 Accepted: 18 April 2013

Published: 27 April 2013

\section{References}

1. Archer GL: Staphylococcus aureus: a well-armed pathogen. Clin Infect Dis 1998, 26:1179-1181

2. Seo KS, Bohach GA: Staphylococcus aureus. In Food Microbiology: Fundamentals and Frontiers. 3rd edition. Edited by Doyle MP, Beuchat LR. Washington, DC, USA: ASM Press; 2007:493-518.

3. Reyher KK, Dufour S, Barkema HW, Des Coteaux L, Devries TJ, Dohoo IR, Keefe GP, Roy JP, Scholl DT: The National Cohort of Dairy Farms - a data collection platform for mastitis research in Canada. J Dainy Sci 2011, 94:1616-1626.

4. Jordan FTW: Poultry Diseases. 6th edition. Philadelphia, PA USA: Saunder Elsevir Lte; 2008:191-195.

5. De Kimpe SJ, Thiemermann C, Vane JR: Role for intracellular plateletactivating factor in the circulatory failure in a model of gram-positive shock. Br J Pharmacol 1995, 116:3191-3198.

6. Donlan RM: Biofilms: microbial life on surfaces. Emerg Infect Dis 2002, 89:881-890

7. Lowy FD: Antimicrobial resistance: The example of Staphylococcus aureus. J Clin Invest 2003, 111:1265-1273.

8. Zechini B, Versace I: Inhibitors of multidrug resistant efflux systems in bacteria. Recent Pat Antiinfect Drug Discov 2009, 41:37-50.

9. Faria $N A$, Oliveira $D C$, Westh $H$, Monnet $D L$, Larsen $A R$, Skov $R$, de Lencastre $H$ : Epidemiology of emerging methicillin-resistant Staphylococcus aureus (MRSA) in Denmark: a nationwide study in a country with low prevalence of MRSA infection. J Clin Microbiol 2005, 43:1836-1842.

10. Chambers HF, DeLeo FR: Waves of resistance: Staphylococcus aureus in the antibiotic era. Nat Rev Microbiol 2009, 7:629-641.

11. Khanna T, Friendship R, Dewey C, Weese SJ: Methicillin resistant Staphylococcus aureus colonization in pigs and pig farmers. Vet Microb 2008, 128:298-303.

12. van Loo I, Huijsdens X, Tiemersma E, de Neeling A, van de Sande-Bruinsma N, Beaujean D, Voss A, Kluytmans J: Emergence of methicillin-resistant Staphylococcus aureus of animal origin in humans. Emerg Infect Dis 2007, 13:1834-1838

13. Garcia-Alvarez L, Holden MT, Lindsay $H$, Webb CR, Brown DF, Curran MD, Walpole E, Brooks K, Pickard DJ, Teale C, Parkhill J, Bentley SD, Edwards GF, Girvan EK, Kearns AM, Pichon B, Hill RL, Larsen AR, Skov RL, Peacock SJ, Maskell DJ, Holmes MA: Methicillin-resistant Staphylococcus aureus with a novel mecA homologue in human and bovine populations in the UK and Denmark: a descriptive study. Lancet Infect Dis 2011, 11:595-603.

14. Haran KP, Godden SM, Boxrud D, Jawahir S, Bender JB, Sreevatsan S: Prevalence and characterization of Staphylococcus aureus, including methicillin-resistant Staphylococcus aureus, isolated from bulk tank milk from Minnesota dairy farms. J Clin Microbiol 2012, 50:688-695.

15. Petinaki E, Spiliopoulou I: Methicillin-resistant Staphylococcus aureus among companion and food-chain animals: impact of human contacts. Clin Microbiol Infect 2012, 18:626-634.

16. Côté J, Caillet S, Doyon G, Dussault D, Sylvain J, Lacroix M: Antimicrobial effect of cranberry juice and extracts. Food Control 2011, 22:1413-1418.

17. Harrison JE, Oomah BD, Diarra MS, Ibarra-Alvarado C: Bioactivities of pilotscale extracted cranberry juice and pomace. J Food Process Preserv 2012. doi:10.1111/j.1745-4549.2011.00655.x.

18. Leitão DPS, Polizello ACM, Ito IY, Spadaro ACC: Antibacterial screening of anthocyanic and proanthocyanic fractions from cranberry juice. J Med Food 2005, 8:36-40.

19. Leusink G, Rempel H, Skura B, Berkyto M, White W, Yang Y, Rhee J-Y, Xuan SY, Chiu S, Silversides F, Fitzpatrick S, Diarra MS: Growth performance, meat quality and gut microflora of broiler chickens fed with cranberry extract. Poult $\mathrm{SCi}$ 2010, 89:1514-1523.

20. Wu VC, Qiu X, Bushway A, Harper L: Antibacterial effects of American cranberry (Vaccinium macrocarpon) concentrate on foodborne pathogens. LWT - Food Sci Technol 2008, 41:1834-1841.

21. Diarra MS, Petitclerc D, Lacasse P: Response of Staphylococcus aureus isolated from bovine mastitis to exogenous iron sources. J Dairy Sci 2002, $85: 2141-2148$
22. Oomah BD, Tiger N, Olson M, Balasubramanian P: Phenolics and antioxidative activities in narrow-leafed lupins (Lupinus angustifolius L.). Plant Foods Hum Nutr 2006, 61:91-97.

23. Oomah BD, Blanchard C, Balasubramanian P: Phytic acid, phytase, minerals, and antioxidant activity in Canadian dry bean (Phaseolus vulgaris L.) cultivars. J Agric Food Chem 2008, 56:11312-11319.

24. Clinical and Laboratory Standards Institute: Performance Standards for Antimicrobial Susceptibility Testing, Twenty-First Informational Supplement M100-S21. Wayne, PA, USA: CLSI; 2011.

25. Eliopoulos GM, Moellering RC: Antimicrobial combinations. In Antibiotics in Laboratory Medicine. Edited by Lorian V. Baltimore, MD: Williams and Wilkins; 1996:330-336.

26. Odds FC: Synergy, antagonism, and what the chequerboard puts between them. J Antimicrob Chemother 2003, 52:1.

27. Allard M, Moisan H, Brouillette É, Gervais AL, Jacques M, Lacasse P, Diarra MS, Malouin F: Transcriptional modulation of some Staphylococcus aureus iron-regulated genes during growth in vitro and in a tissue cage model in vivo. Microb Infect 2006, 8:1679-1690.

28. Pruneau M, Mitchell G, Moisan H, Dumont-Blanchette É, Jacob CL, Malouin F: Transcriptional analysis of antibiotic resistance and virulence genes in multiresistant hospital acquired MRSA. FEMS Immunol Med Microbiol 2011, 63:54-64.

29. Muthaiyan A, Silverman JA, Jayaswal RK, Wilkinson BJ: Transcriptional profiling reveals that daptomycin induces the Staphylococcus aureus cell wall stress stimulon and genes responsive to membrane depolarization. Antimicrob Agents Chemother 2008, 52:980-990.

30. Utaida S, Dunman PM, Macapagal D, Murphy E, Projan SJ, Singh VK, Jayaswal RK, Wilkinson BJ: Genome-wide transcriptional profiling of the response of Staphylococcus aureus to cell-wall-active antibiotics reveals a cell-wall-stress stimulon. Microbiology 2003, 149:2719-2732.

31. Mitchell G, Gattuso M, Grondin G, Marsault É, Bouarab K, Malouin F: Tomatidine inhibits replication of Staphylococcus aureus small-colony variants in cystic fibrosis airway epithelial cells. Antimicrob Agents Chemother 2011, 55:1937-1945.

32. Brouillette E, Grondin G, Lefebvre C, Talbot BG, Malouin F: Mouse mastitis model of infection for antimicrobial compound efficacy studies against intracellular and extracellular forms of Staphylococcus aureus. Vet Microbiol 2004, 101:253-262.

33. Borges G, Degeneve A, Mullen WP, Crozier A: Identification of flavonoid and phenolic antioxidants in black currants, blueberries, raspberries, red currants, and cranberries. J Agric Food Chem 2010, 58:3901-3909.

34. Singh AP, Wilson T, Kalk AJ, Cheong J, Vorsa N: Isolation of specific cranberry flavonoids for biological activity assessment. Food Chem 2009, 116:963-968

35. Viskelis P, Rubinskiene M, Jasutiene I, Sarkinas A, Daubaras R, Cesoniene L: Anthocyanins, antioxidative, and antimicrobial properties of American cranberry (Vaccinium macrocarpon Ait.) and their press cakes. J Food Sci 2009, 74:C157-61.

36. Coates A, Halls G, Hu Y: Novel classes of antibiotics or more of the same? Br J Pharmacol 2011, 163:184-194.

37. González-Lamothe R, Mitchell G, Gattuso M, Diarra MS, Malouin F, Bouarab K. Plant antimicrobial agents and their effects on plant and human pathogens. Int J Molecul Sci 2009, 10:3400-3419.

38. Cimolai N, Cimolai T: The cranberry and the urinary tract. Eur I Clin Microbiol Infect Dis 2007, 26:767-776.

39. Foo LY, Lu Y, Howell AB, Vorsa N: A-Type proanthocyanidin trimers from cranberry that inhibit adherence of uropathogenic P-fimbriated Escherichia coli. J Nat Prod 2000, 63:1225-1228.

40. Howell AB: Bioactive compounds in cranberries and their role in prevention of urinary tract infections. Mol Nutr Food Res 2007, 51:732-737.

41. Singh VK, Jayaswal RK, Wilkinson BJ: Cell wall-active antibiotic induced proteins of Staphylococcus aureus identified using a proteomic approach. FEMS Microbiol Lett 2001, 199:79-84.

42. Kuroda M, Kuroda H, Oshima T, Takeuchi F, Mori H, Hiramatsu K: Twocomponent system VraSR positively modulates the regulation of cell-wall biosynthesis pathway in Staphylococcus aureus. Mol Microbiol 2003, 49:807-821.

43. Tomasz A, et al: The Staphylococcal Cell Wall. In Gram Positive Pathogens. 2nd edition. Edited by Fishetti VA. Washington, DC. USA: ASM Press; 2006:443-455

44. Su X, Howell AB, D'Souza DH: Antibacterial effects of plant-derived extracts on methicillin-resistant Staphylococcus aureus. Foodborn Pathog Dis 2012, 9:573-578 
45. Diarra MS, Rempel H, Champagne J, Masson L, Pritchard J, Topp E: Distribution of antimicrobial resistance and virulence genes in Enterococcus spp: characterization of isolates from broiler chickens. Appl Environ Microbiol 2010, 76:8033-8043.

46. Diarrassouba F, Diarra MS, Bach S, Delaquis P, Pritchard J, Topp E, Skura BJ: Antibiotic resistance and virulence genes in commensal Escherichia coli and Salmonella isolated from commercial broiler chicken farms. J Food Prot 2007, 70:1316-1327.

47. Dahiya JP, Wilkie DC, Van Kessel AG, Drew MD: Potential strategies for controlling necrotic enteritis in broiler chickens in post-antibiotic era. Anim Feed Sci Technol 2006, 129:60-88.

48. Jacob J, Pescatore A: Gut Health and Organic Acids, Antimicrobial Peptides, and Botanicals as Natural Feed Additives. In Organic Meat Production and Processing. Edited by Ricke SC, Van Loo EJ, Johnson MG, O'Bryan CA. Oxford, UK: Wiley-Blackwell; 2012:351-378. doi:10.1002/ 9781118229088.ch21.

49. Tow WW, Premier $\mathrm{R}$, Jing $\mathrm{H}$, Ajlouni $\mathrm{S}$ : Antioxidant and antiproliferation effects of extractable and nonextractable polyphenols isolated from apple waste using different extraction methods. J Food Sci 2011, 76:T163-T172.

50. Puupponen-Pimiä R, Nohynek L, Meier C, Kähkönen M, Heinonen M, Hopia A, Oksman-Caldentey K: Antimicrobial properties of phenolic compounds from berries. J Appl Microbiol 2001, 90:494-507.

51. Taylor M, Joerger R, Palou E, López-Malo A, Avila-Sosa R, Calix-Lara T: Eds S. C. Ricke, E. J. Van Loo, M. G. Johnson. In Organic Meat Production and Processing. Edited by Ricke SC, Van Loo EJ, Johnson MG, O'Bryan CA. Oxford, UK: Wiley-Blackwell; 2012:211-237. doi:10.1002/9781118229088.ch13.

doi:10.1186/1472-6882-13-90

Cite this article as: Diarra et al: In vitro and in vivo antibacterial activities of cranberry press cake extracts alone or in combination with $\beta$-lactams against Staphylococcus aureus. BMC Complementary and Alternative Medicine 2013 13:90.

\section{Submit your next manuscript to BioMed Central and take full advantage of:}

- Convenient online submission

- Thorough peer review

- No space constraints or color figure charges

- Immediate publication on acceptance

- Inclusion in PubMed, CAS, Scopus and Google Scholar

- Research which is freely available for redistribution 